Çukurova Üniversitesi Mühendislik Mimarlık Fakültesi Dergisi, 33(3), ss. 93-100, Eylül 2018

Çukurova University Journal of the Faculty of Engineering and Architecture, 33(3), pp. 93-100, September 2018

\author{
Kinematic Analysis of Tractor Engine Crank-Rod Mechanism \\ Abdullah BEYAZ ${ }^{1}$, Metin DAĞTEKIN ${ }^{* 2}$ \\ ${ }^{1}$ Department of Agricultural Machinery and Technologies Engineering, Faculty of Agriculture, \\ Ankara University, Ankara \\ ${ }^{2}$ Ceyhan Technical College, Çukurova University, Ceyhan/Adana
}

Geliş tarihi: 02.08.2018 Kabul tarihi: 15.10.2018

\begin{abstract}
It is necessary to carry out various movements to understand the functions of agricultural machines. These movements are usually taken from the tractor shaft, the hydraulic control system or the wheel. Various mechanisms are used to ensure movement and to make agricultural machinery work. With these mechanisms, the direction and the number of movements can be changed. One of these mechanisms is crank-rod mechanisms and these mechanisms turn various actions into a complex movement. Consequently, the crank-rod mechanism of the tractor motor can be analyzed with limb mechanisms. In this study, the crank-rod mechanism of a tractor motor was dimensioned in different lengths and subjected to the kinematic analysis of MSC ADAMS software. The kinematic analysis of a single crank-rod mechanism for the engine gives important information about the tractor engine. Kinematic evaluation parameters of these mechanisms can be listed as displacement, velocity, and acceleration. These values related to the crank-rod mechanism of the tractor engine are evaluated and presented in the results and discussion section of the research for a better understanding of the kinematic characteristics of the crankrod motion.
\end{abstract}

Keywords: Tractor, Kinematic analysis, Crank-rod mechanism, MSC ADAMS

\title{
Traktör Krank-Biyel Mekanizmasının Kinematik Analizi
}

$\ddot{O} z$

Tarımsal makinalarının işlevlerini anlamak için çeşitli hareketlerin incelenmesi gerekmektedir. Bu hareketler genellikle traktör şaftından, hidrolik kontrol sisteminden veya tekerden alınır. Hareketlerin sağlanması ve tarım makinalarında çalışmalarının yapılması için çeşitli mekanizmalar kullanılmaktadır. Bu mekanizmalarla, hareketlerin yönü ve sayısı değiştirilebilir. Bu mekanizmalardan biri krank-biyel mekanizmasıdır ve bu mekanizmalar çeşitli hareketleri karmaşık bir harekete dönüştürür. Sonuç olarak, traktör motorunun krank-biyel mekanizması uzuv mekanizmaları ile analiz edilebilir. Bu çalışmada, bir traktör motorunun krank-biyel mekanizması, farklı uzunluklarda boyutlandırılmıştır ve MSC ADAMS yazılımının kinematik analizine tabi tutulmuştur. Motor için tek bir krank-biyel mekanizmasının kinematik analizi, traktör motoru hakkında önemli bilgiler verir. Bu mekanizmaların kinematik değerlendirme parametreleri yer değiştirme, hız ve ivme olarak sıralanabilir. Traktör motorunun krank-biyel mekanizmasına ilişkin bu değerler ve krank-biyel hareketinin kinematik özelliklerinin daha iyi anlaşılması için değerlendirilmiş araştırmanın tartışma ve sonuçlar bölümünde sunulmuştur.

Anahtar Kelimeler: Traktör, Kinematik analiz, Krank-biyel mekanizması, MSC ADAMS

*Sorumlu yazar (Corresponding author): Abdullah BEYAZ, abdullahbeyaz@gmail.com 


\section{INTRODUCTION}

A mechanism can be explained as a system that transforms motion and forces from one direction to another. The mechanism can also be thought of as a system that combination of rigid bodies, which combined with kinematic pairs.

Mechanism analysis gives valuable information about the mechanical systems. Analysis, synthesis and systematic are the main of the mechanism analysis technique. Motion studies have been divided into two group: kinematics and dynamics. Kinematic analysis is the study of motion regarding velocity, acceleration, and displacement of the mechanism without regard to forces that cause it. Dynamic analysis is more complex needs more data to account for the forces. Kinematic analysis is a simple task than dynamic analysis and is adequate for many applications involving moving parts.

In the synthesis of mechanisms, it is proposed to build up novel mechanisms with certain moves and desired kinematic properties. Also, kinematic synthesis of mechanics is divided into three sections:

1. Type synthesis: It is the choice of the type of mechanism. For example; crank, gear, rod and chain mechanism. This topic is concerned with many factors such as force, load, cost, durability, appearance.

2. Number synthesis: This synthesis deals with the number of mechanical components that will carry a certain motion.

3. Dimensional synthesis: It deals with the geometry of the mechanics, the calculation of the dimensions. For example; a profile of a camshaft, the dimension calculations for the gears and limbs. Regarding their functions, limbs in the mechanism can also be classified as; fixed limb, driven limb, moving a limb or transmitting limb. The other name of the driving limb is called as entering limb, and this refers that the limb is connected with the energy source of the mechanism [3].
In this study, the crank was dimensioned in different lengths and subjected to kinematic analysis using MSC ADAMS software. Also in the literature, Akay et al. [1] used the Working Model 8.0.1 software for these kinds of analyzes and they stated that there is much commercial software for mechanism displacement, velocity, and acceleration analysis. Khemili et al. [4] performed a kinematic analysis of a crank mechanism with a flexible crank-rod connection using the MSC ADAMS software. Turkkan and Jun Su [6] express that a lot of mathematical formulations have been developed for kinematic analysis of complex mechanisms, but the analysis of models based equations are sometimes error-prone, because of this reason analysis has been done by using MSC ADAMS software. Sapietova et al. [7] imply that for a virtual prototype in a specific software environment requires to good knowledge with a lot of experience. $\mathrm{Li}$ et al. [8] said that dynamic analysis is essential for the design and application of complex mechanisms, especially for high-speed applications.

\section{MATERIALS AND METHODS}

\subsection{Material}

Crank is an elbowed shaft that transforms the linear movement of the piston into a rotational motion. The crank shape depends on the type of motor and the number of cylinders. The crank's primary task is to create a rotational momentum. Dimensions of crank-rod mechanisms used in the analysis are given in Table 1. Different angles were selected for measurements. The time intervals of each measurement angle value are given in Table 2.

Velocity, acceleration and displacement parameters of these mechanisms are evaluated using kinematic analysis and results are presented in this study.

\subsubsection{Modeling with the MSC ADAMS Software}

MSC ADAMS 'expansion means that "Advanced Dynamic Analysis of Mechanical Systems." This software is a general purpose commercial 
simulation software. The software includes several sub-modules for various simulations such as Flex, Car, Chassis, Driveline, Insight, and Vibration. It is largely utilized in auto and train designs, as considerably as in many other industries. In this work, the software was used in the study of agricultural machinery engineering for the analysis of the crank - rod mechanism of the tractor engine.
The primary usage of ADAMS is the preparation of prototypes with the virtual environment of MSC ADAMS software. By this way system parameters can be better kept and manipulated.

When the MSC ADAMS software is first opened, a setting window appears to name the model, and this window can be used to specify the unit system to used (Figure 1).

Table 1. Dimensions and properties of crank-rod mechanisms used in this work

\begin{tabular}{|c|c|c|c|}
\hline Properties of the crank-rod mechanism & Mechanism 1 & Mechanism 2 & Mechanism 3 \\
\hline Crank Length $(\mathrm{cm})$ & 12.5 & 15 & 17.5 \\
\hline Crank Width $(\mathrm{cm})$ & 3 & 3 & 3 \\
\hline Crank Thickness (cm) & 7 & 7 & 7 \\
\hline Cranking Starting Angle (Degrees) & 90 & 90 & 90 \\
\hline Crank Material & Steel & Steel & Steel \\
\hline $\begin{array}{l}\text { Material Density } \\
\left(\mathrm{Kg} / \mathrm{mm}^{\wedge} 3\right)\end{array}$ & 7.801E-006 & 7.801E-006 & 7.801E-006 \\
\hline Young Module (Newton / mm^2) & $2.07 \mathrm{E}+005$ & $2.07 \mathrm{E}+005$ & $2.07 \mathrm{E}+005$ \\
\hline Poisson's Ratio & 0.29 & 0.29 & 0.29 \\
\hline Crank Cycle (Degree/Sec) & 18000 & 18000 & 18000 \\
\hline Direction of crank cycle & Counter-clockwise & Counter-clockwise & Counter-clockwise \\
\hline Rod Length $(\mathrm{cm})$ & 25 & 25 & 25 \\
\hline Rod width $(\mathrm{cm})$ & 2 & 2 & 2 \\
\hline Rod Thickness (cm) & 3 & 3 & 3 \\
\hline Rod Material & Steel & Steel & Steel \\
\hline Material Density $\left(\mathrm{kg} / \mathrm{mm}^{\wedge} 3\right)$ & $7.801 \mathrm{E}-006$ & $7.801 \mathrm{E}-006$ & $7.801 \mathrm{E}-006$ \\
\hline $\begin{array}{l}\text { Young Module } \\
\left(\text { Newton } / \mathrm{mm}^{\wedge} 2\right)\end{array}$ & $2.07 \mathrm{E}+005$ & $2.07 \mathrm{E}+005$ & $2.07 \mathrm{E}+005$ \\
\hline Poisson's Rate & 0.29 & 0.29 & 0.29 \\
\hline
\end{tabular}

Table 2. The time intervals and angles

\begin{tabular}{|c|c|}
\hline Angle (Direct) & Time (Sec) \\
\hline 0 & 0 \\
\hline 45 & 0.0025 \\
\hline 90 & 0.0050 \\
\hline 135 & 0.0075 \\
\hline 180 & 0.0100 \\
\hline
\end{tabular}




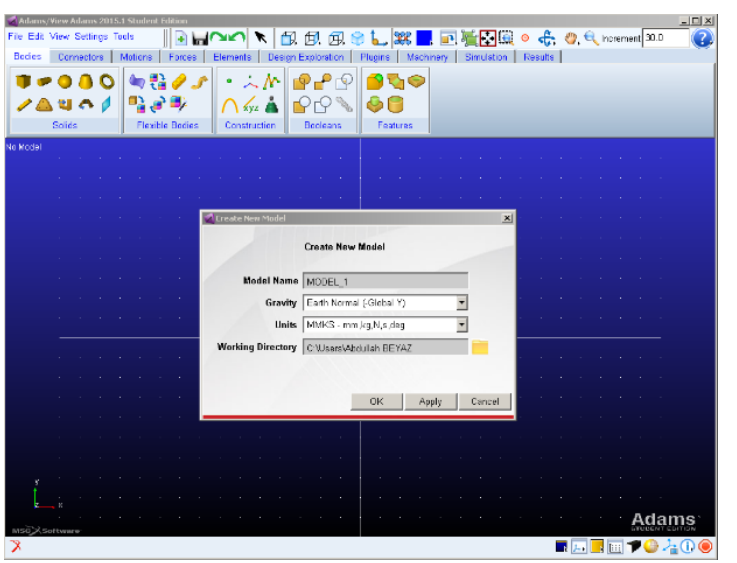

Figure 1. Unit system setting window

After naming the model and choosing the unit system, the interface of the ADAMS software consisting of the basic toolbar and userspace appears on the screen (Figure 2).

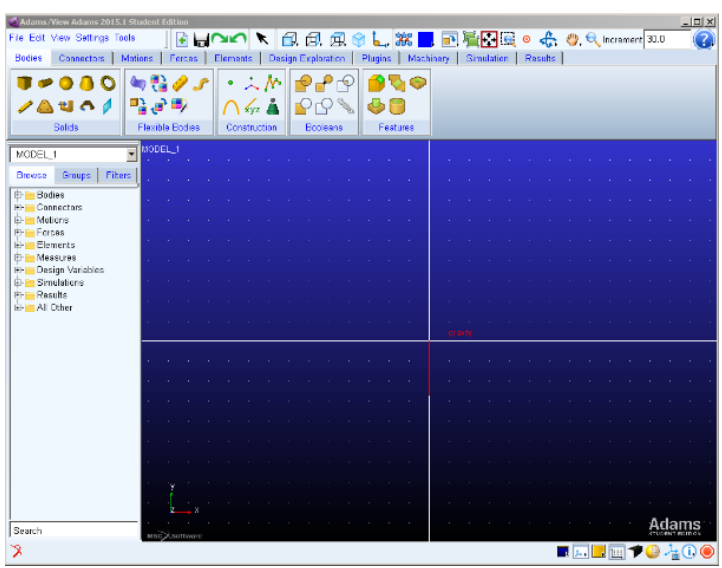

Figure 2. The interface of the MSC ADAMS software

The main toolbar of the software offers many selections for the main characters used in the kinematic analysis as indicated in Figure 3.

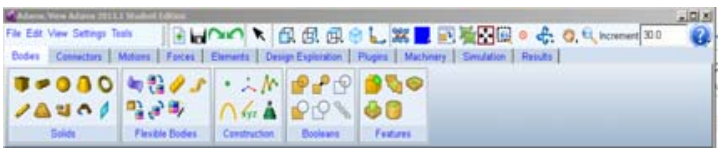

Figure 3. Basic toolbar and main components

Figure 4 shows the kinematic pair selection bar (upside), and the movement toolbar (downside).

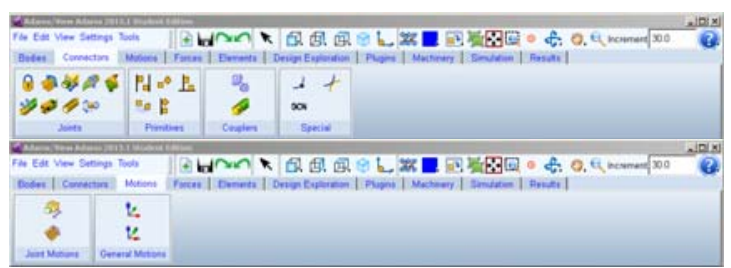

Figure 4. The kinematic pair toolbar (upside) and motion toolbar (downside)

Assigning material properties to the main parts is possible. Assignment of these properties of the material can be done by using material properties assignment window shown in Figure 5.

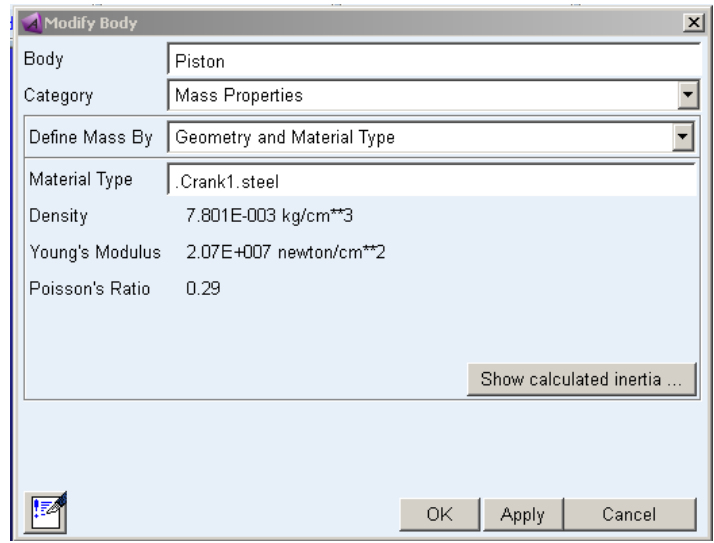

Figure 5. Material properties assignment window

The types of movements given to agricultural machines are usually made up of alternative and turning movements. Fig. 6 shows the motion setting window for this operation, which can be used for determining the number of rotations and the movement characteristics.

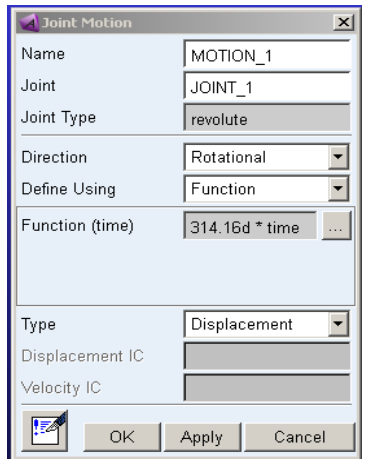

Figure 6. Motion setting window 
Also the simulation model of the crank - rod mechanism can be seen as shown in Figure 7.

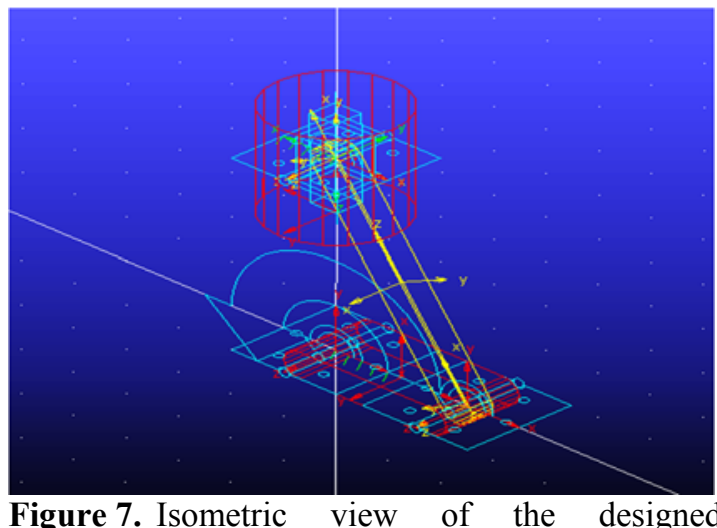

Figure 7. Isometric view of the designed crankshaft mechanism simulation model

The basic steps for crack-rod mechanism model analysis can be seen in Figure 8.

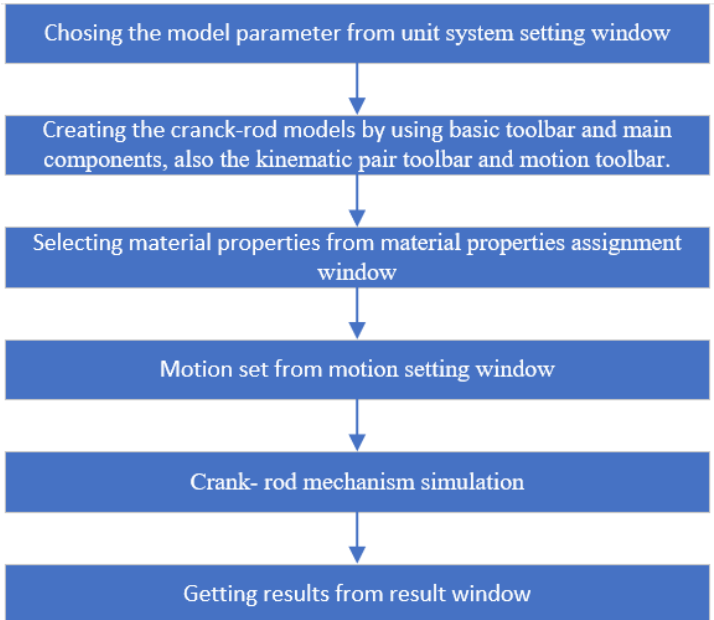

Figure 8. The basic steps for crack-rod mechanism model analysis

\section{RESULTS AND DISCUSSION}

It is significant to select an optimum crank - rod mechanism in the appropriate dimensions for the optimum engine operation. The parameters such as compact structure, good force transmission, low periodic loading, low interference and vibration values, optimum transmission angle and good compatibility are effected from crank - rod dimensions. Therefore these parameters have been considered for the selection of an appropriate mechanical design between mechanical systems (Figure 9). The resulting interface for the analysis results and the animation of designed model can be obtained as shown in Figure 10.

The parameters that limit us in engine design are the stroke length, the crank, and the rod lengths, which can change the force transmission efficiency of the mechanism. The $\mu_{\min }$ values of the three simulated mechanisms are presented in Table 3.

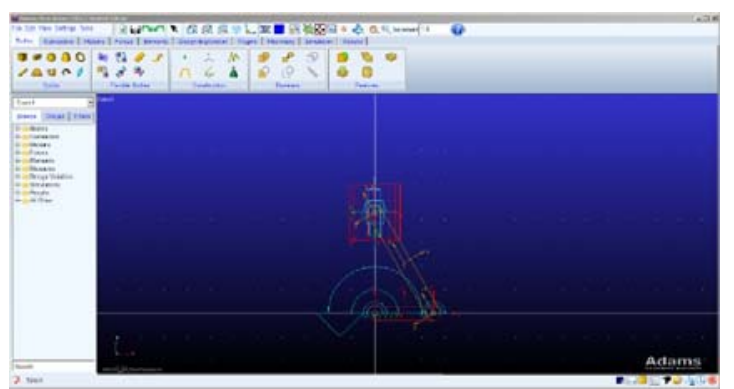

Figure 9. Crank- rod mechanism simulation model

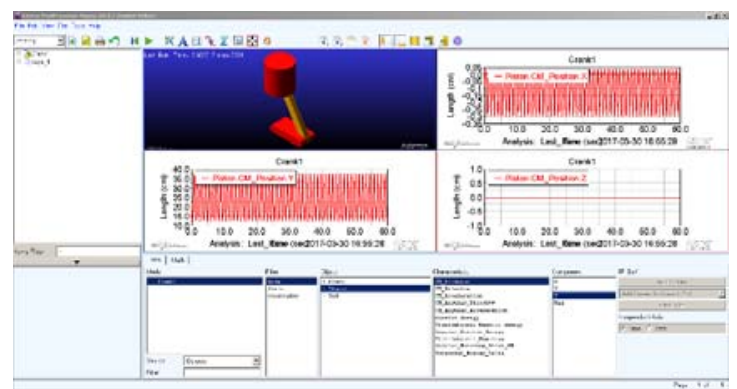

Figure 10. Result display interface

Table 3. Forge transmission values of crank-rod mechanisms

\begin{tabular}{|l|c|}
\hline \multicolumn{2}{|c|}{ Transmission Angle (Degree) $\boldsymbol{\mu}_{\min }$} \\
\hline Mechanism 1 & 60 \\
\hline Mechanism 2 & 52.5 \\
\hline Mechanism 3 & 45 \\
\hline
\end{tabular}

When Table 3 is examined, it is seen that the $\mu_{\min }$ angle is increased when the size of the rod increases. The efficiency of the mechanism is also increasing as the $\mu_{\min }$ angle approaches to $90^{\circ}$. The displacement - time, velocity - time, acceleration time curves were found using the MSC ADAMS 
software to define the kinematics of mechanisms. Rane et al. [5] conducted a computer-aided simulation of a sheep shearing machine in their work and compared the calculated values with the MSC ADAMS results for mechanism analysis.
Also, we have found comparable results like literature as given in Table $4-8$. When we look at the tables, we see that MSC ADAMS displacement, velocity and acceleration values nearly the same with calculated values from formulas.

Table 4. Calculated (C) ADAMS output of crank according to $0^{\circ}$ crank start value

\begin{tabular}{|l|r|r|r|}
\hline & Mechanism 1 & Mechanism 2 & Mechanism 3 \\
\hline $\mathbf{C}_{\mathbf{~}} \mathbf{( m m )}$ & 375.0 & 400.0 & 425.0 \\
\hline ADAMS & 375.0 & 400.2 & 424.5 \\
\hline $\mathbf{C}_{\mathbf{~} \mathbf{~} \mathbf{~} \mathbf{m m} / \mathbf{s})}$ & 0 & 0 & 0 \\
\hline ADAMS $_{\mathbf{v}}$ & 0 & 0 & 0 \\
\hline $\left.\mathbf{C}_{\mathbf{a}} \mathbf{( m m} / \mathbf{s}^{\mathbf{2}}\right)$ & $18505 \mathrm{E}+007$ & $23687 \mathrm{E}+007$ & $29362 \mathrm{E}+007$ \\
\hline ADAMS $_{\mathbf{a}}$ & $18501 \mathrm{E}+007$ & $23679 \mathrm{E}+007$ & $29382 \mathrm{E}+007$ \\
\hline
\end{tabular}

Table 5. Calculated (C) ADAMS output of crank according to $45^{\circ}$ crank start value

\begin{tabular}{|l|r|r|r|}
\hline & Mechanism 1 & Mechanism 2 & Mechanism 3 \\
\hline $\mathbf{C}_{\mathbf{~ s}} \mathbf{( m m )}$ & 322.80 & 333.6 & 343.1 \\
\hline ADAMS $_{\mathbf{~}}$ & 321.4 & 332.5 & 341.0 \\
\hline $\mathbf{C}_{\mathbf{~} \mathbf{~} \mathbf{( m m} / \mathbf{s})}$ & 37581.4 & 47453.9 & 58111.7 \\
\hline ADAMS $\mathbf{~}_{\mathbf{2}}$ & 38373.1 & 48829.9 & 61195.3 \\
\hline $\left.\mathbf{C}_{\mathbf{a}} \mathbf{( m m} / \mathbf{s}^{\mathbf{2}}\right)$ & $87223 \mathrm{E}+006$ & $10466 \mathrm{E}+007$ & $12211 \mathrm{E}+007$ \\
\hline ADAMS $_{\mathbf{a}}$ & $89553 \mathrm{E}+006$ & $11405 \mathrm{E}+007$ & $14909 \mathrm{E}+007$ \\
\hline
\end{tabular}

Table 6. Calculated (C) ADAMS output of crank according to $90^{\circ}$ crank start value

\begin{tabular}{|l|r|r|r|}
\hline & Mechanism 1 & Mechanism 2 & Mechanism 3 \\
\hline $\left.\mathbf{C}_{\mathbf{~}} \mathbf{( m m}\right)$ & 218.80 & 205.0 & 188.8 \\
\hline ADAMS $_{\mathbf{~}}$ & 216.05 & 200.6 & 177.1 \\
\hline $\left.\mathbf{C}_{\mathbf{v}} \mathbf{( m m} / \mathbf{s}\right)$ & 39270.0 & 47124.0 & 54978.0 \\
\hline ADAMS $_{\mathbf{~}}$ & 38963.6 & 46921.1 & 55592.5 \\
\hline $\left.\mathbf{C}_{\mathbf{~}} \mathbf{( m m} / \mathbf{s}^{\mathbf{2}}\right)$ & $61685 \mathrm{E}+006$ & $8882 \mathrm{E}+007$ & $12090 \mathrm{E}+007$ \\
\hline ADAMS $_{\mathbf{~}}$ & $71311 \mathrm{E}+006$ & $10982 \mathrm{E}+007$ & $17316 \mathrm{E}+007$ \\
\hline
\end{tabular}

Table 7. Calculated (C) ADAMS output of crank according to $135^{\circ}$ crank start value

\begin{tabular}{|l|r|r|r|}
\hline & Mechanism 1 & Mechanism 2 & Mechanism 3 \\
\hline $\mathbf{C}_{\mathbf{~}} \mathbf{( m m )}$ & 146.00 & 121.5 & 95.7 \\
\hline ADAMS $_{\mathbf{~}}$ & 145.54 & 121.0 & 91.9 \\
\hline $\left.\mathbf{C}_{\mathbf{v}} \mathbf{( m m} / \mathbf{s}\right)$ & 17946.4 & 19179.5 & 19627.1 \\
\hline ADAMS $_{\mathbf{~}}$ & 17196.9 & 17851.9 & 16384.1 \\
\hline $\left.\mathbf{C}_{\mathbf{~}} \mathbf{( m m} / \mathbf{s}^{\mathbf{2}}\right)$ & $87223 \mathrm{E}+006$ & $104667 \mathrm{E}+007$ & $12211 \mathrm{E}+007$ \\
\hline ADAMS $_{\mathbf{~}}$ & $81489 \mathrm{E}+006$ & $93139 \mathrm{E}+007$ & $10093 \mathrm{E}+007$ \\
\hline
\end{tabular}


Table 8. Calculated (C) ADAMS output of crank according to $180^{\circ}$ crank start value

\begin{tabular}{|l|r|r|r|}
\hline & Mechanism 1 & Mechanism 2 & Mechanism 3 \\
\hline $\mathbf{C}_{\mathbf{s}}(\mathbf{m m})$ & 125.0 & 100.0 & 75.0 \\
\hline ADAMS $_{\mathbf{s}}$ & 125.0 & 100.2 & 74.5 \\
\hline $\mathbf{C ~}_{\mathbf{v}}(\mathbf{m m} / \mathbf{s})$ & 0 & 0 & 0 \\
\hline $\mathbf{A D A M S}$ & 0 & 0 & 0 \\
\hline $\mathbf{C}_{\mathbf{~}}\left(\mathbf{m m} / \mathbf{s}^{\mathbf{2}}\right)$ & $61685 \mathrm{E}+006$ & $59217 \mathrm{E}+007$ & $51815 \mathrm{E}+007$ \\
\hline ADAMS $_{\mathbf{a}}$ & $61697 \mathrm{E}+006$ & $59286 \mathrm{E}+007$ & $51560 \mathrm{E}+007$ \\
\hline
\end{tabular}

When the tables are examined, it is seen that the zero values are in the dead positions.

Based on the simulation performed, the following results can be mentioned in this study like literature $[2]$.

1. The results of complex changes on mechanisms using computer simulation tools and software can be seen in a short time.

2. Based on these simulation results, the design changes can be made via this simulation software to increase the performance of the mechanism.

3. The solutions obtained using the analytical formulas were applied to find out the accuracy of the results obtained from the MSC ADAMS software.

4. It is possible to test many rigid elements and kinematic pairs which we imagined and designed in our mind in a simple and ideal way considering factors such as force transmission and mechanical efficiency.

\section{REFERENCES}

1. Akay, O.E. 2009. Development Prototype Machine Based Orbit at Harvesting of K. Maraş Red Chili Pepper Department of Agricultural Machinery, Institute of Natural and Applied Sciences, University of Çukurova, Ph.D. Thesis.

2. Balli, S.S., Chand, S. 2002. Defects in Link Mechanisms and Solution Rectification. Mechanism and Machine Theory, 37, 851-876.
3. Kazıhan, K., Okutan, B., Aslan, Z. 1996. Machine and Mechanism Theory. Beta Publishing, Publication No: 621, Technical Series: 28, ISBN 975-486-516-7

4. Khemili, I., Romdhane, L. 2008. Dynamic analysis of a flexible slider-crank mechanism with clearance. European Journal of Mechanics, 27, 882-898.

5. Rane, S., Grover, V., Vashista, V., Jere, A., Saha, S.K. 2007. Computer Aided Analysis of A Sheep Shearing Machine. CD-Proc. Of the Nat. Conf. on Emerging Trends in Mechanical Engineering, 4-5, 1-10.

6. Turkkan, O. A., Jun Su, H., 2017. A General and Efficient Multiple Segment Method for Kinetostatic Analysis of Planar Compliant Mechanisms. Mechanism and Machine Theory, 112, 205-217.

7. Sapietova, A., Bukovan, J., Sapieta, M., Jakubovicova, L., 2017. Analysis and Implementation of Input Load Effects on an Air Compressor Piston in MSC.ADAMS. Procedia Engineering, 177, 554-561.

8. Li, N., Jun Su, H., Peng Zhang, X., 2017. Accuracy Assessment of Pseudo-Rigid-Body Model for Dynamic Analysis of Compliant Mechanisms. J. Mechanisms Robotics 9(5), 054503, Aug 04. 
